\title{
Social Changes And Conflicts In Orang Sekaum In The North Halmahera Peace Zone
}

\author{
Abubakar Muhammad Nur \\ Postgraduate, Sociology Study Program, Faculty of Social and Political Sciences \\ Universitas Brawijaya, Malang, Indonesia \\ Sociology Study Program, Faculty of Social and Political Sciences \\ University of Muhammadiyah North Maluku, INDONESIA
}

Sanggar Kanto

Sociology Study Program, Faculty of Social and Political Sciences

Universitas Brawijaya, Malang, INDONESIA

Darsono Wisadirana

Sociology Study Program, Faculty of Social and Political Sciences

Universitas Brawijaya, Malang, INDONESIA

\author{
I. Nyoman Nurjaya \\ Law Study Program, Faculty of Law \\ Universitas Brawijaya, Malang, INDONESIA
}

\begin{abstract}
The civilization of "orang sekaum" (ethnic Tobelo) in its development, follows the dynamics of social change that leads to social conflict. Conflict and violence between brothers in "orang sekaum" gave birth to two different poles in a vulgar way (Islam vs. Christian). The process of social change and the development of "orang sekaum" is characterized by a climate of social life that previously lived in a harmonious and peaceful state, turned into conflict between brothers in the peace zone. Communities are provoked and powerless over the presence of migration in North Halmahera, from various regions as victims of previous conflicts and violence. The impact of this violent incident is directly proportional to the instability of the social control castle embodied in the cultural values of "Hibua Lamo" as the social glue and kinship of "orang sekaum" Therefore, horizontal riots soon take place with the same reason and language, each maintaining self-esteem on the basis of beliefs and religions it embraces.
\end{abstract}

Keywords: Social Change, Conflict, Orang Sekaum, Peace Zone.

\section{INTRODUCTION}

"Orang sekaum" (ethnic Tobelo) is a social group living and interacting within the same social system that decide a certain position based on the similarity of lineage, custom and language, under the auspices of the traditional values of "Hibua Lamo" as the legacy of ancestor, since it was in Lake Lina Outback Halmahera. Hibua Lamo (large house) is a traditional body of orang sekaum or ethnic Tobelo who function as a gathering place for the people, to "berhigaro" (deliberation), and serves as a social glue. Hibua Lamo has become a philosophy of life for ethnic Tobelo, although this ethnicity is due to its development, they have spread in various regions of North Maluku, but the cultural values of Hibua Lamo remain the basis of kinship for ethnic Tobelo. Symbols used such as communication tools are the language "O Tobeloho" (the language of the Tobelo people) and "Hibua Lamo" (big house), as a symbol of social glue. At 
certain times, if there is a customary or other social event that arises in social life, then Hibua Lamo as a gathering place and "berhigaro" (deliberation), to solve social problems, followed by ethnic Tobelo from various regions. Tobelo in addition to the Central Government of North Halmahera Regency, is also an ethnic area of Tobelo ethnic, which is a zone of peace.

A very strong kinship system has been inherited by Tobelo ethnic ancestors, based on customary values "O 'Adati de 0' Galiti" (Adat and Rules / values and norms), as a foundation for building and maintaining the attitude of "O Dora - 0 'Hayangi " (affection). Since they were still in Telaga Lina Outback Halmahera, Tobelo's ethnic ancestors were not familiar with the religion of the sky. After they migrated (from Telaga Lina to the coast) of the North Halmahera peninsula, then they recognize the divine religion introduced by missionaries (Christians) and mubaligh (Islam). Over the introduction, they then divided and embraced the religion that they believed (Islam and Christian), voluntarily and sought after by their parents or family. Although they have different religions, the dynamics of community life remain harmonious under the auspices of the cultural values of Hibua Lamo, as the basis of social harmony for the "orang sekaum" or by local people known as "ethnic Tobelo" and or "Hibua Lamo" community.

The ethnic mention of Tobelo and the Hibua Lamo community, to local communities is essentially the same. When meeting with local people, both at the same time with different people, and or at different times with same people, there is often a term used by ethnic Tobelo and or the Hibua Lamo community. According to Papilaya (2011), "Hibua Lamo community" and "ethnic Tobelo", can be called one class or, "orang sekaum". For local people, especially the laity, the term "ethnic Tobelo and the Hibau Lamo community, has the same meaning. The difference is the Hibua Lamo community known as the ethnic Tobelo who live and settle in the Tobelo Region and surrounding areas (customary area) under the auspices of customary institutions (Hibua Lamo). While the ethnic Tobelo known as one of the largest ethnic, which in addition to being in the Tobelo Region also has spread, live and settle in various areas in North Maluku Province. Tobelo ethnic that has spread beyond Tobelo, is not known as the "Hibua Lamo community", but is more commonly known as the ethnic Tobelo. In this article, researchers focus on the ethnic Tobelo in the Tobelo Region (customary area), known as the Hibua Lamo community, using the term "Orang Sekaum" as a representation of the ethnic term Tobelo and the Hibua Lamo community. Indeed, these orang sekaum have a strong kinship system as a legacy of civilization from the ancestors.

Human civilization in its development always follow the dynamics of social change, where each tribe undergoes constantly changing changes in the creation of a new order in a society. Change is a process of transformation that occurs in the structure of society, both in the mindset, and the pattern of behavior that lasts from time to time (Marcionis, 1987). Every society contributes to the conflict and each conflict will produce a change (Dahrendorf, 1958, 1559). Cultural growth is not always as fast, parts grow or change rapidly, while other parts grow and / or change slowly (Greenfield et al., 2003). if the occurrence of a change in a society that took place deliberately, then the conflict was always accompanying the process of change.

"Orang Sekaum" who had embraced divine religion, they were in a zone of peace, meaning they were in a customary area, so that in social life, acknowledging each other's position, caring and respecting each other. Respect is the need of every involved party, while the insistence on a common position is the factor that creates justice (Leasa \& Samallo, 2014; Leasa \& Batlolona, 2017; Leasa et al., 2017). The culture of "orang sekaum" respects each other, so that they always live in harmony and peace, but in its development it turns out to be dissolving in dispute between brothers of different religion (Islam vs Christian). Why should they conflict? Whereas they are brothers of the same ancestors. 


\section{DISCUSSION FOCUS}

"Orang Sekaum" (ethnic Tobelo) residing in the Hibua Lamo customary area, in Tobelo Halmahera Utara, are in the social life marked by the treatment of customs. Under the foundations of Hibua Lamo's customary values, they always lived in harmony and peace. In 1999, "Orang Sekaum" was involved in open conflict (mutual killing) between brothers that was triggered by different religions (Islam vs Christian). Why should they conflict? whereas they were brothers, from the same ancestor in Lake Lina in the Halmahera hinterland. The focus of the discussion in this article, moving from the process of social change and the background of conflicts between brothers in the "orang sekaum" in the customary area, as a zone of peace in North Tobelo Halmahera.

\section{CONFLICT IN PEACE ZONE IN SOCIAL CHANGE PERSPECTIVE Social Changes In "Orang Sekaum"}

The demands of development era has direct influence on social change in "Orang Sekaum" (ethnic Tobelo). Starting from previous ancestral life in Lake Lina in the Halmahera hinterland, they took their life naturally (gardening, hunting for wild animals, dressing, building houses, and other traditional lifestyles and social life). Papilaya (2011) says that "people inhabited the lake Lina hereditary, referred to as "Orang Sekaum" about three hundred years ago.

The "Orang Sekaum", then traveled and spread to the expanses of the earth in North Halmahera, fueled by a desire to reestablish the sovereignty of the ancestral kingdom, the Moro Kingdom, and the maritime heroic spirit (Changa), with the interaction of the coastal world had abandoned their ancestors before. After being on the coast, then forming a group of "Orang Sekaum" in several stretches in the North Halmahera region, then they form the village or "Hoana". The people are divided into ten Hoana, namely: 1) Hoana Modole, 2) Hoana Pagu, 3) Hoana Boeng, 4) Hoana Towiliko, 5) Hoana Morodina or Towara, 6) Hoana Morodai or Toweka, 7) Hoana Lina, 8) Hoana Gura and 9) Hoana Mumulati and 10). Hoana Huboto (Papilaya, 2011). The ten Hoana, scattered in the North Halmahera region.

In the 17th century, 150 or 200 Tobelo people had settled in some Gulfs, now known as the settlements of the Tobelo people (Amal, 2013), known as "0 'Tobelo hoka" (members of Tobelo society). The tribe is often nomadic or nomadic, because it is not only settled in the Tobelo region. However, it is scattered and settled also in some areas, Kao, Morotai and Bacan. They also spread throughout South Halmahera and Seram. In its development, "Orang Sekaum" have spread throughout the region, but they continue to maintain their holistic kinship. The customary values of Hibua Lamo remain a symbol of social glue. The process of "Orang Sekaum" dispersion in these areas is accompanied by the formation of new communities and villages that have consequences of intermingling with other groups of different cultures, and proceeds in a modern way.

There is nothing in modern society that in its life does not experience the process of interacting with others who have different cultures and leads to change. Both changes influenced by internal and external factors that can affect the existence of cultural values it has, and conflict is one of the ignorant dynamics of change. In the perspective of sociology, conflict and change always coincide with the dynamics in social life. In the era of globalization today, no society does not experience social change. The concept of change related to time and social change refers to a process within the social system, where there are differences that can be measured or observed over a period of time (Kanto, 2011).

Change is the process of transformation that occurs within the structure of society and within the mindset and patterns of behavior that take place from time to time (Macionis, (1987). 
Conflict can change and directly affect the relationship of a society and can also lead to change in civilization in societies concerned. The social change is not an intuitive fact, in which a phenomenon or a change that only some people agree, as a change nor does it mean something similar to intuitive facts. However, some people consider something that happens as a change, and certain groups consider it not as a change (Lauer \& Lauer, 1991).

Every society contributes to the conflict, and each conflict will result in a change (Dahrendorf, 1959; Burrows \& Kinney, 2016). Each community group has a different social structure, according to social conditions and the growth of the culture in which the social environment of the community resides. The functionalists said that every element of society plays a role in maintaining stability. While, theoretical conflicts see various elements of society contribute to disintegration and change. If a negative change comes and cannot be managed wisely, it will also influence the customary and religious order in a particular society that encourages fragile social control.

Human bodies have various parts that are interconnected with each other. Therefore, various institutions are interconnected and dependent on each other. This concept of a system to describe the harmonious coordination between the institutions. Every human body has a clear and distinctive function, so too does every institutional form in society. Each institution carries out specific tasks for stability and well-being. "Orang sekaum" has a social control institution (Hibua Lamo), as an institution that serves as a social glue. The existence of Hibua Lamo since ethnic Tobelo was still not a religion of the sky until they embraced Islam and Christianity. Issues that occur in society, can be answered by looking for what factors integrate a society (Van den Berghe (1967) Culture of mutual respect, uphold, love, and always give respect to fellow human beings, a reflection of the norms, values and morals embodied in the philosophy of Hibua Lamo, as a means of social integration.

Basically, the community is integrated on the basis of the agreement of its members on certain social values, and is a general agreement, which has the power to overcome differences of interest among members of society. Thus, the members of society have a balance in their positions. The paradigm of conflict theory sees society as an arena where the inequalities exist within and potentially lead to conflict and change (Acemoglu, 2003; Mikkelsen \& Clegg, 2017). The emergence of conflicts can give birth to a change and / or change can also give birth to a conflict in the life of society. The consequences of development can change the civilization of a people against the pattern of community life. "Orang sekaum" have also a development that changes civilization that leads to religious conflict between brothers as the consequences.

\section{INTERCULTURAL CONFLICTS IN ORANG SEKAUM}

"Orang sekaum" (ethnic Tobelo), known as the "calical" society that inherits a culture of mutual recognition and mutual respect, based on the philosophy of cultural values of Hibua Lamo, as the foundation of kinship, to preserve social stability. On the other hand, in its development, the society also dissolved in religion dispute between brothers (Islam vs Christian). People survive in many ways, that the world as a stable and ongoing entity, is struck with endurance, family, religion and other well-organized social institutions. Any society as a wide network of connected parts, where each part helps to maintain the system as a whole (Mele et al., 2010).

Departing from the philosophy of Hibua Lamo, then orang sekaum (ethnic Tobelo), in fact they always live in a peaceful atmosphere and do not have to kill each other en masse, as happened in 1999-2001. The social life order of the Orang Sekaum societies, that is, the culture behaves fairly toward all people. For Orang Sekaum, All men are created in the same degree, except the behavior of each person. Conflict is a social phenomenon that is universal and inherent in the 
life of society, both in social interaction between individuals and between individuals with groups. It is therefore impossible for a "calical" society to avoid conflict in the dynamics of social life. Conflict must be managed, controlled and resolved, together wisely and peacefully, in order not to develop into violence, anarchy or destructive, which leads to disintegration or destruction of the joints of social relations in people's lives (Coser \& Rosenberg, 1968). The very nature of social reality is conflict, therefore conflict is a social reality that can be found everywhere (Raho, 2014).

The conflict that happened openly between brother in "orang sekaum" in North Halmahera, is a series of conflicts in various regions of North Maluku Province before, such as conflicts between adherents of religion (Islam vs Christian) in Tidore, conflicts between groups of society, i.e. white groups (in combination with various ethnic groups in Southern Ternate) vs. yellow groups (in combination with the Christians and Muslims of indigenous councils of the Ternate Sultanate, in northern Ternate and its surrounding) in Ternate, conflicts between faiths (Islam vs Christian) in West Halmahera, ethnic conflict Kao with Makian ethnicity in Malifut, North Halmahera. The conflicts took place at the same time, as a result of the horizontal conflict in Ambon in 1999 (Muhammad Nur, 2013b).

The background of the conflict and violence of various regions above varied, according to the sociological conditions of the local community. In Tobelo, for example, religion conflict between brothers (Islam vs. Christian) openly (killing each other), whereas they were brothers as Tobelo ethnic from the same ancestors. Basically the Tobelo conflict was triggered by the initial conflict between Muslims and Christians in Tobelo (Duncan, 2008, 2009a, 2013, 2016). The impact of the Tobelo conflict, not only material losses, casualties, but also paralyzing the social institutions that feared community groups (Tindage, 2006). In fact all religious teachings, especially Islam and Christianity teach their people to believe that God is worshiped holy. All religions teach their people to do things that are in accordance with God's will, compassion and forgiving life One of the roles and functions of religion to reconcile from the conflict One of the important functions of religion is to reconcile the contradictions of life (Marrill, 1987).

"Orang Sekaum" are brothers who has different religion (Moslems and Christians) of the same ancestors. In social life, they have a very strong kinship system, under the auspices of the Hibua Lamo culture values, why should they conflict? This is the involvement of religion in the traces of violence in Indonesia based on the supremacy of religious understanding and conscience, as well as negative fanaticism (Hamim, 2007). Conflict refers to a situation in which a group of people with identities are clearly involved in conscious contradiction with one or more of the other groups, because the groups teach and strive to achieve conflicting goals (Coser, 1956). In social life, conflict always occurs, often using religious issues because it is seen as a sexy issue to wage a conflict (Surwandono \& Ahmadi, 2011).

The process of development and change in "Orang Sekaum" boils down to the dynamics of community life, from previously in the zone of peace, changed instantly into conflict between brothers. The state of "Orang Sekaum" (ethnic Tobelo) since its ancestors remained in Telaga Lina until after being on the North Hamahera coast (before 1999), their kinship system remained well preserved. The atmosphere of social life is always reflected in the attitude of " $O$ 'dora $O$ ' hayangi" (affection). Social dynamics are always built in an atmosphere of affection, mutual respect, mutual acceptance, mutual recognition and mutual care, and mutual respect, turning into an attitude of sentiment towards fellow people of different religions. 
Kinship values that are always embodied in social life, such as mutual cooperation work or the term known in "orang sekaum" is called "bahirono". When one party from a community member is doing a job, whether a private job, such as a residence, or a job for the public interest, such as building a house of worship (mosque and church), the system of "bahorono" (mutual cooperation), becomes a prima donna in life socially. The kinship system was destroyed instantaneously by the conflict of anti-liberalism in the peace zone. The circumstances of the "Orang Sekaum" changed instantaneously from harmonious life, inherited by the ancestors with the system "O 'dora $O$ ' hayangi" (affection) and "O'tohora-moi" (as blood and descendants). The situation turned into a state of "Galosiri" (sorrow), which is a state of society in conflict (1999-2001). In this period the open religion conflict between brothers seemed to run in a relay.

The series of conflicts succeeded in changing the kinship climate of "O'tohora-moi" (as blood and descendants), changing the map into differences between adherents of religion (Islam vs Christian). The social life of society in the "sassum" in this era is no longer under control. The kinship system embodied in the philosophy of Hibua Lamo, becomes fragile. In this era, the community kinship climate has been provoked, each taking choice and attitude according to the aqidah and beliefs adopted. "Orang Sekaum" was soon mapped into two poles in a vulgar way (Islam and Christian). The fragility of Hibua Lamo's cultural values, as the social glue for "Orang Sekaum" has a direct effect on the volatility of social control over the wave of conflict coming from outside. Because of this event, the peace map of "orang sekaum" in the customary area was destroyed instantly. Conflict can increase social adjustment, the conflict begins with the demands of a reward ratio, a social structure that can be either closed or in an open form (Coser \& Rosenberg, 1969).

Types of problems concerning the influence of conflicts or a conflict are functional to the social system. Conflict is the most important element in human life, where conflict has a positive function (Coser \& Rosenberg, 1969). Conflict becomes a dynamics in the entity's relationship always with social relations (Dahredorf, 1959), conflict is part of the process for the fulfillment of basic human needs (Doucey, 2011). According to Marx, social conflict is the opposition between segments of society to compete for valuable assets. Various kinds of social conflicts according to Marx, conflict between individuals, conflicts between groups, conflicts between nations (Raho, 2014). The nature of the theory applies universally but can not be generalized, depending on sociological conditions, country, region and or local community.

Violent conflict in pastoral areas is caused by many socio-cultural, economic and political factors that reinforce one another, by limiting the availability and reduction of access to natural resources (Opiyo et al., 2012). Everywhere people compete to get the natural resources they need. Competition for use and access to natural resources leads to conflict. Conflict also arises from differences in cultural values, social norms and sanctions related to access to natural resources (Uprety, 2006). Residents in northern Ghana identified three major catalysts of armed conflict: mutual disrespect between ethnic groups, land controversies, and endemic violence cultures (Yelyang, 2016). Different types of conflicts arise according to the social variants that exist in the region. The social, political, economic, faith (religious) and / or other injustice issues cause the conflict.

"Orang Sekaum" view at first that religious differences of beliefs are the right of every individual, because they think that all religions have the same purpose, believe in the existence of God and there is the doctrine of compassion toward fellow human beings in it. Many emerging pagan thought of various people or groups, against the teachings of other religions, but they do not understand the meaning contained in these verses have an meaning that can 
only be understood implicitly by the religious scribes concerned. Some assume that the teachings of Islam are always voicing war, and verses are often associated with the issue of war, as in Surat At Taubah verse 5, "And when the sacred months have passed, then kill the polytheists wherever you find them and capture them and besiege them and sit in wait for them at every place of ambush. But if they should repent, establish prayer, and give zakah, let them [go] on their way. Indeed, Allah is Forgiving and Merciful".

Explicitly, the verse mentions the word "kill" because it is also the perception of certain people in certain contexts, made the basis for fighting against others if considered a stumbling block in religious life. If the verse is only read at a glance, then misperception will often occur. Indeed, in the verse is coupled with the Hudaibiyah agreement between the Prophet Muhammad and the polytheists in Makkah. Asbab command on the verse to kill when in fact addressed to the polytheists who clearly violate the agreement. There is another verse that mentions wars, as in Albaqarah verse 190-191, that " Fight in the way of Allah those who fight you but do not transgress. Indeed. Allah does not like transgressor." Furthermore, in verse 191, in Albaqarah's Letter mentions, "And kill them wherever you overtake them and expel them from wherever they have expelled you, and fitnah is worse than killing. And do not fight them at al-Masjid alHaram until they fight you there. But if they fight you, then kill them. Such is the recompense of the disbelievers."

The cry of war, not only is in Qur'an, but there is also in the beginning of other religious teachings. As in the Bible, for example, there is also war cry, as in one of the verses which says, "My arrows will be smeared with their blood, all against Me I kill with my sword, I will not let anyone against me, the prisoner and the wounded must die "(Deuteronomy 32: 42). In another passage in the Gospels, it also says that "When the Lord your God brought you into the land to which you came to possess it, and he drove many nations before you, the Hittites, the Girgashites, the Amorites, the Canaanites, Ferries, Hivites, and Jebusites. Seven nations more numerous and stronger than you, and the LORD your God have given them over to you to strike them down, and you shall utterly crush them: make no covenant with them, pity them "(Deuteronomy 7: 1-2).

Explicitly the verses contained in the holy book (al-Qur'an and Gospel) are exploited by the faceless movers (provocateurs), who make propaganda tools for launching their mission for the sake of a moment's interest. Whereas the truth of religion teaches its people to love each other and always do good among others. In Islam for example, the Qur'an commands so many letters and verses about the teaching of compassion and doing good to others. But in its development, it is often provoked by news that suggests that Islam is not a religion that brings peace, but rather, that religion is seen to teach about violence and become a source of inspiration for terrorism. Likewise, the teachings of Christianity, so that its people always do good, be loving toward others, but often laced with messages that have provocation, which leads to sentiment among religious people.

In the Qur'an, Allah emphasizes that piety is not judged merely in the form of ritual piety, but also in the form of pious deeds and affection that must be practiced in social life. The message of the Qur'an, that "Indeed, Allah orders justice and good conduct and giving to relatives and forbids immorality and bad conduct and oppression. He admonishes you that perhaps you will be reminded." (QS 16:90). There is a group of people, whether consciously or unconsciously, they want to take the political interests of a particular religion, only to reach the goal for a moment, affecting mutual enmity. But none is granted it except those who are patient, and none is granted it except one having a great portion [of good]. "(QS 41: 34-35). 
As in the teachings of the Qur'an that teach about love and affection and do good to others, so also in Christianity through the Gospels also teaches about affection and kindness towards others, but in his paraktik often covered by the news that memorable that Christianity is not a religion of peace but a religion that teaches violence and is a source of inspiration for provocateurs. There are several examples of moral messages through the Gospels include: Matthew, 19: 18, "Do not take vengeance, and hold no grudge against the people of your people, but love your neighbor as yourself. John, 4:21, "And this commandment we receive from Him: Whoever loves God, he must also love his brother". John, 5: 43 "You have heard that it was said, 'Love your neighbor and hate your enemy'. Matthew, 5:44, "But I say unto you, love your enemies and pray for those who obey you". Romans 13: 9, "For the commandments," Do not commit adultery, do not murder, do not steal, do not covet, "and whatever else you say are summed up in this saying, 'Love your neighbor as yourself.'

Religious doctrine is often made of some people as a very sexy issue in legitimizing the struggle and easily involving many people. The Fatwa said acts of violence in the name of religion are often translated by some as "legal doctrine" to be implemented (Hamim, 2007). Conflicts between believers are the most difficult to solve, for beliefs tend to be held firmly by their adherents and will sometimes be defended until death. Violent incidents with religious issues, as a justification for religious violence, have become an issue that adorns the history of violence in various regions. Religion has always been the escalator of conflict, by a faceless movement (provocateur), for the fulfillment of momentary interest.

\section{CONCLUSION}

The change of civilization in the "Orang Sekaum" in its development follows the dynamics of change that leads to social conflict. Conflict and violence in "Orang Sekaum" gave birth to two different poles in a vulgar way (Islam vs. Christian). Such events can destroy the kinship system that has been inherited by their ancestors as ethnic Tobelo. The process of social change and development in the Hibua Lamo community, characterized by a social climate of life in "Orang Sekaum" who previously lived in a harmonious state, turned into conflict and religious nuance violence in the peace zone.

There are two points of view which can corner the "Orang Sekaum" position in the holistic system of kinship, turning into a position of mass arena of dispute: First, the attitude of neglect of the existence of Hibua Lamo's customary values, such as "O 'dora de $O$ ' hayangi" (love and affection), "O'tohora-moi", "O 'adati de $O$ ' galiti" (customs and rules / values and norms), and $O$ 'baliara "(kestiakawanan). Second, the disbelieving attitude of thinking on the religious teachings followed, the following backfire for "Orang Sekaum" that can destroy the kinship system " $O$ ' Tobelo hoka" in the life of society.

\section{Reference}

Acemoglu, D. (2003). Why Not A Political Coase Theorem? Social Conflict, Commitment, and Politics. Journal of Comparative Economics, 31, 620-652.

Burrows, K., \& Kinney. P. (2016). Exploring the Climate Change, Migration and Conflict Nexus. International Journal of Environmental Research and Public Health, 13, 1-17.

Coser, L. A. (1956). The Functios of Social Conflict, New York: Free Press.

Coser, L., \& Rosenberg. (1969). Sociological Theory: A Book of Reading, Third Edition, The Macmillan Company. London.

Dahrendorf, R. (1958). Toward a Theory of Social Conflict. The Journal of Conflict Resolution, 2(2), 170-183

Dahrendorf, R. (1959). Class and class conflict in industrial society. USA. Stanford, Calif: Stanford University Press. 
Doucey, M. (2011). Understanding The Root Causes of Conflicts: Why it Matters for International Crisis Management. International Affairs Review, 20(2), 1-12

Duncan, C. R. (2008). Where Do We Go from Here? The Politics of Ending Displacement in Post-Conflict North Maluku." In Conflict, Violence, and Displacement in Southeast Asia: Patterns, Dynamics, and Experience, edited by Eva-Lotta Hedman, 207-230. Ithaca: Cornell Southeast Asia Program.

Duncan, C. R. (2009a). "Monuments and Martyrdom in the Aftermath of Communal Violence in North Maluku." Bijdragen tot de Taal-, Land- en Volkenkunde, 165(4), 429-458.

Duncan, C. R. (2013). Violence and Vengeance: Religious Conflict and Its Aftermath in Eastern Indonesia. Ithaca: Cornell University Press.

Duncan, C. R. (2016). Coexistence not Reconciliation: From Communal Violence to Non-Violence in North Maluku, Eastern Indonesia. The Asia Pacific Journal of Anthropology, 17(5), 460-474.

Greenfield, P. M., Keller, H., Fuligni, A., \& Maynard, A. (2003). Cultural Pathways Through Universal Development. Annual Review of Psychology, 54, 461-90.

Hamim, T. (2007). Resolusi Konflik Islam Indonesia,LSAS dan IAIN Sunan Ampel Press.

Kanto, S. (2011). Perspektif Modernisasi Dan Perubahan Sosial. Malang: UB Press.

Lauer \& Lauer, 1991. The Long-Term Relational Consequences of Problematic Family Backgrounds. Family Relations, 40(3), 286-290.

Leasa, M., \& Batlolona, J. R. (2017). Full Day School dalam Pembentukan Karakter Siswa SMKN 13 Kota Malan [Full Day School in Student Character Formation SMKN 13 Malang]. Jurnal Ilmu Sosial dan Humaniora, 6(1), 73-82.

Leasa, M., \& Samallo, R. (2014). Learning Motivation of Students in Ambon Child-Friendly School, Moluccas. Education, 4(2), 41-51.

Leasa, M., Corebima, A. D., Ibrohim., \& Suwono, H. (2017). Emotional Intelligence among Auditory, Reading, and Kinesthetic Learning Styles of Elementary School Students in Ambon-Indonesia. International Electronic Journal of Elementary Education, 10(1), 83-91.

Macionis, J. (1987). Sociology. New Jersey: Prentice Hall.

Mele, C., Pels, J., \& Polese, F. (2010). A Brief Review of Systems Theories and Their Managerial Applications. Service Science, 2(1/2), 126-135.

Merril, W. L. (1986). Religion and Culture: God's Saviours in the Sierra Madre, dalam buku: Conformity and Conflict. Reading in Cultural Anthropology Six, Little, Brown.

Mikkelsen, E. N., \& Clegg, S. (2017). Conceptions of Conflict in Organizational Conflict Research: Toward Critical Reflexivity. Journal of Management Inquiry, 1-14.

Muhammad Nur, Abubakar. (2013b). Merajut Damai Di Maluku Utara: Telaah Konstrukstif Konflik Malifut 19992000 [Knitting Peace In North Maluku: Constructive Studies Malfut Conflict 1999-2000]. Ternate: UMMU Press.

Opiyo, F. E.O, Oliver, V. W., Janpeter, S., \& Stephen, M. M. (2012). Resource-based conflicts in drought-prone Northwestern Kenya: The drivers and mitigation mechanisms. Wudpecker Journal of Agricultural Research, 1(11), 442-453.

Papilaya, E. J. (2011). Kharisma Hibua Lamo, Tutur Kearifan Kepemimpinan Budaya, Tobelo [Kharisma Hibua Lamo, Tutur Wisdom of Cultural Leadership, Tobelo]: Pemda Halut.

Raho, B. (2014). Sosiologi, Yogyakarta: IKAPI.

Surwandono \& Ahmadi, S. (2011). Resolusi Konflik di Dunia Islam [Conflict Resolution in the Islamic World], Yogyakarta, Grahayu Ilmu.

Tindage, R. (2006). Damai yang sejati: Rekonsiliasi di Tobelo, kajian teologi dan komunikasi [True peace: Reconciliation in Tobelo, theological and communications studies].Jakarta: YAKOMA-PGI.

Uprety, D. R. (2006). Conflicts in natural resource management-Examples from community forestry, Published 2006 in the Jahrbuch der.

Van den Berghe, P. L. (1967). Race and Racism: A Comparative Perspective. New York: Wiley.

Yelyang, A. (2016). Conflict Prevention Strategies in Northern Ghana: A Case Study of the Ethnic Conflicts in Kpemale. Journal of Conflict Transformation \& Security, 5(1), 76-94. 